\title{
Horizontal Cylindrical Structures in an Unconsolidated Quaternary Deposit at Saint-Joachim, Near Québec City (Canada)
}

\section{Structures cylindriques horizontales dans un dépôt meuble quaternaire à Saint-Joachim, près de la municipalité de Québec}

\author{
Jean-Claude Dionne et Simon Laliberté
}

Volume 59, numéro 1, 2005

URI : https://id.erudit.org/iderudit/013738ar

DOI : https://doi.org/10.7202/013738ar

Aller au sommaire du numéro

Éditeur(s)

Les Presses de l'Université de Montréal

ISSN

0705-7199 (imprimé)

1492-143X (numérique)

Découvrir la revue

Citer cette note

Dionne, J.-C. \& Laliberté, S. (2005). Horizontal Cylindrical Structures in an Unconsolidated Quaternary Deposit at Saint-Joachim, Near Québec City (Canada). Géographie physique et Quaternaire, 59(1), 75-80.

https://doi.org/10.7202/013738ar
Résumé de l'article

Deux séries de structures cylindriques horizontales ont été observées récemment dans un dépôt deltaïque émergé mis en place à la fin du Pléistocène (11-10 ka BP), à une quarantaine de kilomètres au nord-est de la municipalité de Québec. Sises à $19 \mathrm{~m}$ de profondeur, les structures cylindriques occupent un lit de sable fin, légèrement oxydé, inséré entre deux couches d'argile silteuse, bleue, compacte, respectivement de 35 et $45 \mathrm{~cm}$ d'épaisseur. La longueur maximale atteinte par les structures est inconnue en raison de l'exploitation avancée de la gravière. Toutefois, dans la partie restante, dégagée manuellement, elles ont une longueur minimale comprise entre 34 et $59 \mathrm{~cm}$. Le centre des cylindres est composé de sable, moyen à grossier, non stratifié alors que l'enveloppe extérieure de quelques centimètres d'épaisseur est constituée de sable fin, oxydé et semi-induré. Les structures horizontales ont été formées après la mise en place du dépôt par un écoulement souterrain d'eau sous pression hydraulique provenant d'une cuvette peu profonde produite par un affaissement local. La pression a été suffisamment forte pour créer des cavités de type suffosion. Lors de la baisse de pression, elles ont été comblées par des sédiments plus grossiers que la couche encaissante. L'eau, qui a migré parallèlement aux couches, devait s'écouler sur le front du delta. Ces structures cylindriques horizontales semblent les premières du genre à avoir été observées dans un dépôt meuble quaternaire.
Tous droits réservés @ Les Presses de l'Université de Montréal, 2006
Ce document est protégé par la loi sur le droit d'auteur. L'utilisation des services d'Érudit (y compris la reproduction) est assujettie à sa politique d'utilisation que vous pouvez consulter en ligne.

https://apropos.erudit.org/fr/usagers/politique-dutilisation/ 


\section{Notes}

\section{HORIZONTAL CYLINDRICAL STRUCTURES IN AN UNCONSOLIDATED QUATERNARY DEPOSIT AT SAINT-JOACHIM, NEAR QUÉBEC CITY (CANADA)}

Jean-Claude DIONNE* and Simon LALIBERTÉ** : Département de géographie and Centre d'études nordiques, Université Laval, Québec, Québec G1K 7P4, Canada.

ABSTRACT Two series of six horizontal cylindrical structures (pipes) were discovered recently in a Late Pleistocene (11-10 ka BP) emerged delta deposit about $40 \mathrm{~km}$ NE of Québec City, Canada. The pipes occur at a depth of $19 \mathrm{~m}$ in a slightly oxydized layer of fine sand which is interlayered with two strata of compact blue silty clay, respectively 35 and $45 \mathrm{~cm}$ in thickness. The maximum length of the pipes is not known, but the remaining exhumed pipes measure 34 to $59 \mathrm{~cm}$. Their diameter ranges from 6.5 to $14.5 \mathrm{~cm}$. The pipe core generally consists of clean and loose medium to coarse sand whereas the outer ring, made of oxydized fine sand, is semi-consolidated. Pipes are the result of water flow in a permeable sand layer enclosed between two nonpermeable layers; water enclosed in a shallow basin created by local collapsing was under hydraulic pressure and forced to drain out on the delta front. These water escape features are possibly the first known site of horizontal cylindrical structures observed in unconsolidated Quaternary sediments.

\section{INTRODUCTION}

Sedimentary cylindrical structures are a particular type of structure having the shape of a pipe. They are usually vertical, sometimes oblique, crossing through horizontal or subhorizontal strata. Those occurring in consolidated bedrock were reported long ago (Kavanagh, 1888-1889; Todd, 1896) and were first confused with fossil tree logs. The large vertical pipes in the Postdam sandstone of Ontario (Dionne, 1960) have been described at length and explained as the result of hydraulic pressure related to artesian springs (Hawley and Hart, 1934). Since then, many other locations in various countries have been discovered, reported and attributed also to artesian springs when the sediments were unconsolidated (Dionne and Pérez Alberti, 2000: Table II, p. 344).

Manuscrit reçu le 8 mars 2005 ; manuscrit révisé accepté le 27 septembre 2005 (publié le $3^{\mathrm{e}}$ trimestre 2006)

* Adresse actuelle: 2761 rue de Valcourt, Québec, Québec G1W 1V9, Canada ; dionne.morissette@globetrotter.net

** Adresse actuelle: 106 rue Rolland-Chagnon, app. 17, Saint-Basilele-Grand, Québec J3N 1L4, Canada ; lalib11@ hotmail.com
RÉSUMÉ Structures cylindriques horizontales dans un dépôt meuble quaternaire à Saint-Joachim, près de la municipalité de Québec. Deux séries de structures cylindriques horizontales ont été observées récemment dans un dépôt deltaïque émergé mis en place à la fin du Pléistocène (11-10 ka BP), à une quarantaine de kilomètres au nord-est de la municipalité de Québec. Sises à $19 \mathrm{~m}$ de profondeur, les structures cylindriques occupent un lit de sable fin, légèrement oxydé, inséré entre deux couches d'argile silteuse, bleue, compacte, respectivement de 35 et $45 \mathrm{~cm}$ d'épaisseur. La longueur maximale atteinte par les structures est inconnue en raison de l'exploitation avancée de la gravière. Toutefois, dans la partie restante, dégagée manuellement, elles ont une longueur minimale comprise entre 34 et $59 \mathrm{~cm}$. Le centre des cylindres est composé de sable, moyen à grossier, non stratifié alors que l'enveloppe extérieure de quelques centimètres d'épaisseur est constituée de sable fin, oxydé et semi-induré. Les structures horizontales ont été formées après la mise en place du dépôt par un écoulement souterrain d'eau sous pression hydraulique provenant d'une cuvette peu profonde produite par un affaissement local. La pression a été suffisamment forte pour créer des cavités de type suffosion. Lors de la baisse de pression, elles ont été comblées par des sédiments plus grossiers que la couche encaissante. L'eau, qui a migré parallèlement aux couches, devait s'écouler sur le front du delta. Ces structures cylindriques horizontales semblent les premières du genre à avoir été observées dans un dépôt meuble quaternaire.

Besides, similar structures occurring in Quaternary unconsolidated deposits have been reported only thirty years ago (Dionne and Laverdière, 1972; Dionne, 1973; Dionne and Gangloff, 1975; Gangloff, 1974; Curran and Frey, 1975) and more recently by Jensen and Miller (1990) and by Dionne and Pérez Alberti (2000). Despite their uniqueness, these structures are not illustrated in most current manuals and atlas of sedimentary structures (Gubler, 1966; Conybeare and Crook, 1968; Picard and High, 1973; Collinson and Thompson, 1982; Allen, 1984; Ricci Lucchi, 1995). However, Pettijohn and Potter (1964: Plate 115A), illustrate a cylindrical structure in a Tertiary sandstone formation in Japan whereas Plate 114 shows a sand volcano with a pipe about $35-40 \mathrm{~cm}$ in diameter.

Horizontal cylindrical structures are a similar sedimentary feature, but the pipes are horizontal and parallel to strata. They are apparently uncommon because only one paper (Allen, 1961) has mentioned their occurrence in association with vertical pipes in Devonian strata in England. In the book Clastic tidal facies (Klein, 1977: p. 58), figure 58 illustrates a particular sedimentary feature which appears to be a horizontal cylindrical structure in the Lower Member of Wood Canyon Formation (Precambrian), near Lathrop Wells, Nevada. However, this 
structure, which is $12 \mathrm{~cm}$ long (minimum) and $4 \mathrm{~cm}$ in diameter, was likely misinterpreted as a "pseudonodule" in an ancient tidal flat deposit. To our knowledge, horizontal pipes have not been observed, reported or described in unconsolidated deposits. A paper by Baerman et al. (1983: Fig. 279, p. 262) shows a ring structure exposed in a vertical section into a Quaternary unconsolidated sand deposit overlaid by till in Denmark. The structure, about $45 \mathrm{~cm}$ in diameter, is apparently in a horizontal position but the length is not visible. The outer ring consists of carbonates whereas the core is made of clay and iron. However, this curious sedimentary structure is not identified as a pipe. It is the purpose of this note to report the occurrence of horizontal pipes in a marine Late Glacial delta deposit near Québec City, Canada.

\section{GEOGRAPHIC AND GEOLOGIC SETTING}

The study site is a delta located at Saint-Joachim, a locality on the north shore of the St. Lawrence estuary, approximately
40 km NE of Québec City ( $70^{\circ} 51^{\prime} 05^{\prime \prime}$ W, $\left.47^{\circ} 04^{\prime} 20^{\prime \prime} \mathrm{N}\right)$. The delta section is a few hundred meters SE of National road 138 and along a secondary road leading to the village of SaintJoachim (Fig. 1). It is about $1.5 \mathrm{~km} \mathrm{SE}$ of the present course of the Rivière Sainte-Anne and $3 \mathrm{~km} \mathrm{NW}$ of the St. Lawrence modern shoreline.

This emerged delta was built into the postglacial Goldthwait Sea during ice retreat (LaSalle, 1978; Lebel, 2001; Laliberté, 2005). The section is in an abandoned sand pit on a remaining frontal portion of the delta which forms an erosion escarpment $80 \mathrm{~m}$ high.

At the exposure, the surface of the delta lies at $123 \mathrm{~m}$ asl. The thickness of the deposit exceeds $100 \mathrm{~m}$ but only the upper $55 \mathrm{~m}$ were exposed in 2003. The vertical sequence is composed of four units (Fig. 2). At the base (between 49 and $56 \mathrm{~m}$ below the surface), unit 1 is a thick homogeneous coarse sand characterized by a few thin laminae of heavy minerals. The second unit (between 42 and $49 \mathrm{~m}$ ) is a contorted or turbated laminated silt and fine sand bed. The third unit, a rhythmic

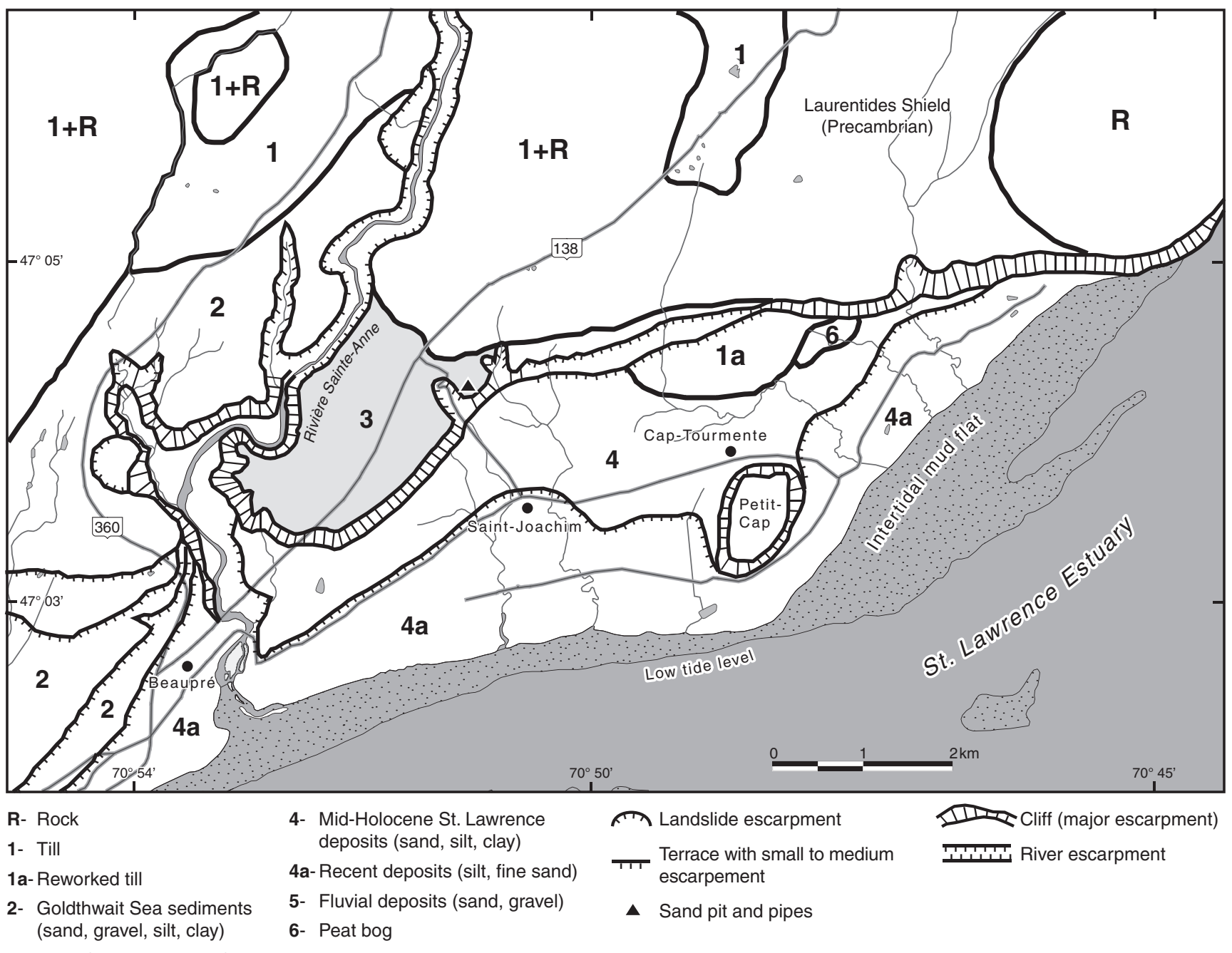

3- Delta (sand, gravel, silt)

FIGURE 1. Location of the study area, locality names and main geomorphologic features.
Localisation de l'aire d'étude, noms de lieux et cartographie géomorphologique sommaire. 


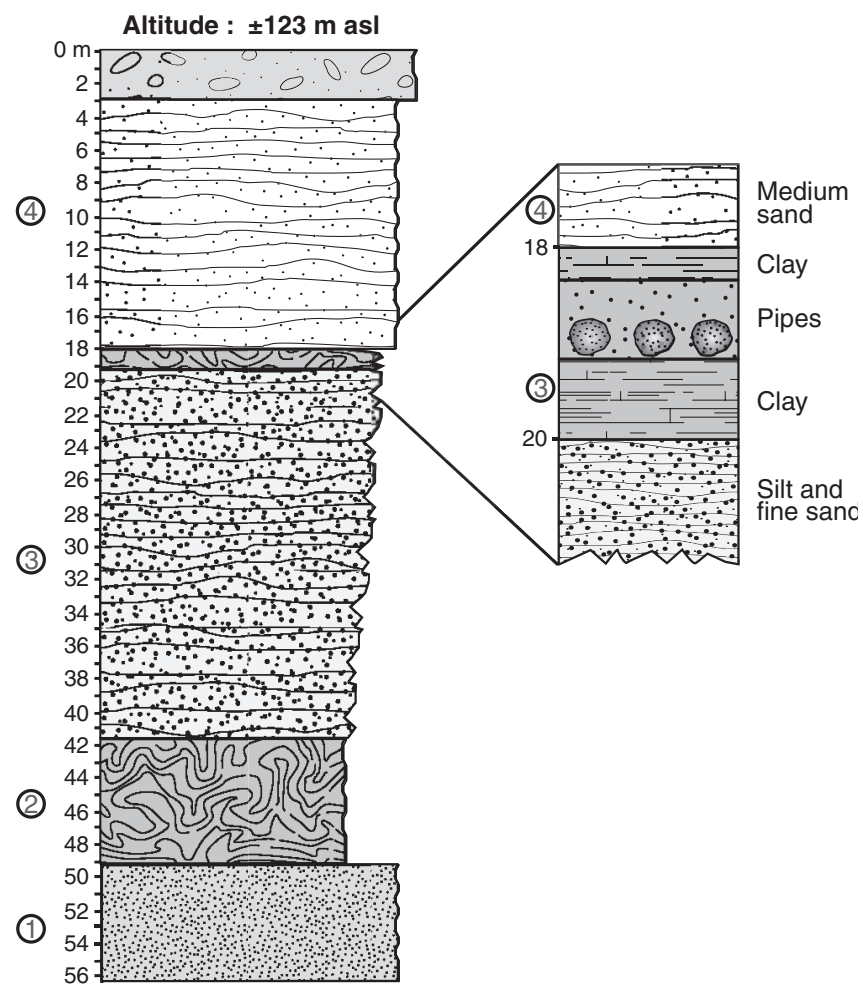

FIGURE 2. Vertical section in the emerged delta of Rivière SainteAnne at Saint-Joachim, near Québec City.

Coupe verticale dans la partie frontale du delta de la rivière SainteAnne, à Saint-Joachim, près de Québec.

deposit $23 \mathrm{~m}$ thick, is composed of interlayered laminated silt and fine to medium sand with a few thin clay layers in the upper part of the unit (18 to $28 \mathrm{~m}$ ), and of grey fine to medium sand, thinly stratified and partly oxydized between 28 and $41 \mathrm{~m}$. At the top of unit 3, at a depth between $18-20 \mathrm{~m}$, is a subunit composed of two clay layers enclosing a fine sand layer in which the pipes occur. The overlying unit 4 is $18 \mathrm{~m}$ thick and consists of horizontally stratified medium to coarse sand; the upper $3 \mathrm{~m}$ of unit 4 contain gravel, pebbles and cobbles. At the exposure, strata in the four units dip slightly toward SSW, i.e. toward the St. Lawrence Valley.

Fine sand and silt layers between 24 and $30 \mathrm{~m}$ depth contain fossils of the following species: Hiatella arctica, Macoma balthica, Macoma calcarea and Mya arenaria. The latter species is often found with both shells in growth position. A sample of mixed shells at a depth of $24.5 \mathrm{~m}$ gave a ${ }^{14} \mathrm{C}$ age of $10950 \pm 50 \mathrm{BP}$ (Beta-180 456). An another ${ }^{14} \mathrm{C}$ date, $10100 \pm 120 \mathrm{BP}$ (GSC-5851), from a sandy layer at a depth of $17.5 \mathrm{~m}$, i.e. slightly above the pipes, has been obtained in the section studied by Lebel (2001).

\section{CHARACTERISTICS OF CYLINDRICAL STRUCTURES}

Cylindrical structures were observed at the top of the third unit about $19 \mathrm{~m}$ below the surface of the deposit. To the right of the pipes, the strata are deformed, swelling into a few meters wide anticline-like structure. The pipes occur near this intraformational ridge in a shallow depression (syncline) in which layers dip slightly inland.

The first cylindrical structures observed by Lebel (2001) (Fig. 3) were found in an adjacent exposure about $30 \mathrm{~m}$ farther. Unfortunately, the six pipes then exhumed were not described and interpreted. A new excavation in 2003 had allowed the exhumation of a new series of pipes.

The six pipes then observed occur in a subunit composed of a $30 \mathrm{~cm}$ layer of fine sand interlayered with two blue silty clay layers respectively $25-30$ and $40-45 \mathrm{~cm}$ in thickness (Fig. 2). The pipes are parallel, straight, closed, and from 3 to $25 \mathrm{~cm}$ apart (Fig. 4; Table I). They are oriented north-south, parallel to strata, and dip 6 to 9 degrees inland. Pipes are circular in outline (Fig. 5). In the series observed by Lebel (2001), the pipes were smaller, more rounded and regular in shape. Hand excavation exhumed pipes over 34 to $59 \mathrm{~cm}$ in length; the diameter of pipes ranges from 6.5 to $14.5 \mathrm{~cm}$. Typically, pipes are composed of an outer ring of oxydized semiindurated fine sand a few centimeters thick, and a core of structureless medium to coarse, light grey, clean, friable and permeable sand. At the base of each pipe is a sole made of compact and slightly oxydized silty fine sand (Fig. 6). Pipe No. 4 was a twin pipe whereas pipe No. 5 was characterized by two dome-like structures located at the surface of the pipe; a very small pipe $15 \mathrm{~cm}$ long and $1.5 \mathrm{~cm}$ in diameter was attached to the left side of this pipe. Pipe No. 3 shows a slightly different inner structure with a twin core of medium sand (Fig. 7). Grain size of the sand filling the inner part of pipes is illustrated in figure 8.

\section{MODE OF FORMATION}

The horizontal pipes observed at Saint-Joachim (Québec) are tubular semi-lithified ducts in unconsolidated fine sand. They were formed by water flowing under pressure through a permeable sand layer squeezed between two non permeable or nearly impermeable silty clay layers. Water was first concentrated in a shallow depression created by localized subsidence of the sediments in the upper section of unit 3 . The cause of the subsidence is not known precisely but is likely related to the weight of the overlying sandy gravel unit, $18 \mathrm{~m}$ in thickness, exerting vertical pressure on the underlying silt and fine sand rhythmites when they were still water-saturated.

The pipe section examined did not show any evident constrictions indicating fluctuations of the water flow. The pressure was such that extrusion of sand created an empty cyclindrical cavity (suffosion hole). When the pressure decreased the cavity was then filled with structureless and friable medium to coarse sand derived from a layer not visible in the section. Because water was iron-rich, oxydation of fine sand of the outer ring occurred at the same time giving a semi-lithified character to the pipes.

Although the limited length of the exhumed pipes does not allow us to depict them fully, we did not find any evidence that the horizontal pipes are part of a more complex system composed of horizontal, oblique and vertical cyclindrical structures 

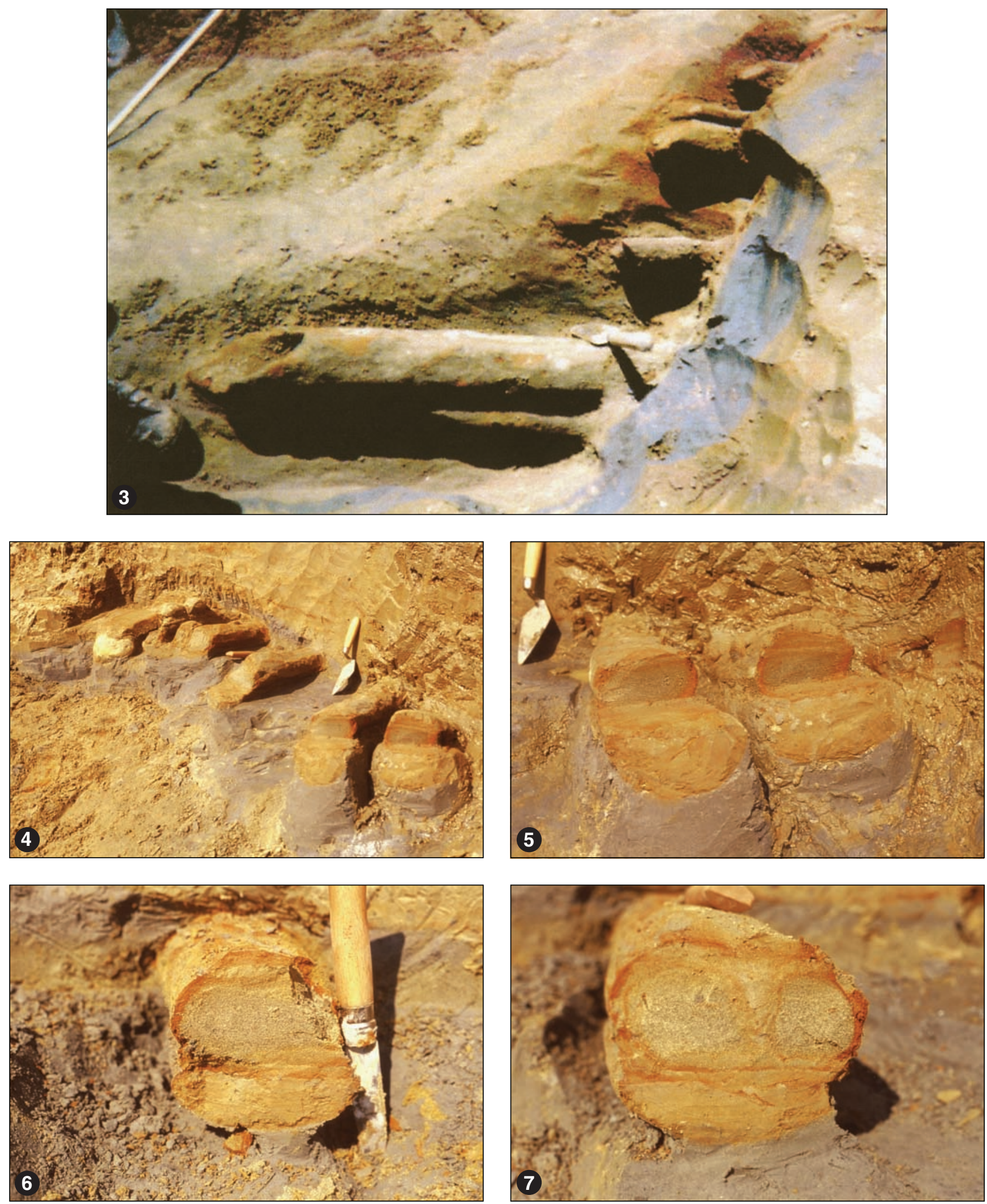
FIGURE 3. The first series of horizontal pipes observed by Martin Lebel in 2000.

Première série de structures cylindriques horizontales découvertes par Martin Lebel en 2000.

FIGURE. 4. The second series of horizontal pipes observed by the authors in 2003. Pipes are aligned at the surface of a blue clay layer $40-45 \mathrm{~cm}$ thick.

Deuxième série de structures cylindriques horizontales dégagées par les auteurs en 2003. Les structures sont alignées à la surface d'une couche d'argile limoneuse bleue de 40-45 cm d'épaisseur.

FIGURE 5. A typical horizontal pipe in the emerged Sainte-Anne delta. The medium sand core of pipe is surrounded by a ring of oxydized fine sand; at the base is a sole of compacted and slightly oxydized silty fine sand.

Structure cylindrique horizontale typique dans le delta de la rivière Sainte-Anne ; la partie centrale du cylindre (le noyau) est composée de sable moyen à grossier lessivé alors que la partie extérieure (l'enveloppe) est constituée de sable fin oxydé ; la base de la structure est composée de sable fin limoneux oxydé.

FIGURE 6. Two parallel pipes at the top of a blue clay layer. Pipes are composed of a medium to coarse sand core surrounded by a ring of oxydized fine sand whereas the lower portion forming a sole is slightly compacted and oxydized silty fine sand.

Deux structures cylindriques horizontales parallèles juste au-dessus de la couche d'argile bleue; la partie interne des structures est composée de sable moyen à grossier alors que la partie externe est constituée d'une mince couche de sable fin oxydé ; la base de la structure comprend une semelle de sable fin oxydé.

FIGURE 7. A pipe $14.5 \mathrm{~cm}$ in diameter with a double core of medium to coarse sand; note the sole of slightly compacted and oxydized silty fine sand.

Une structure cylindrique horizontale de $14,5 \mathrm{~cm}$ de diamètre montrant un double noyau de sable moyen à grossier ; remarquez la semelle à la base composée de sable limoneux partiellement oxydé.

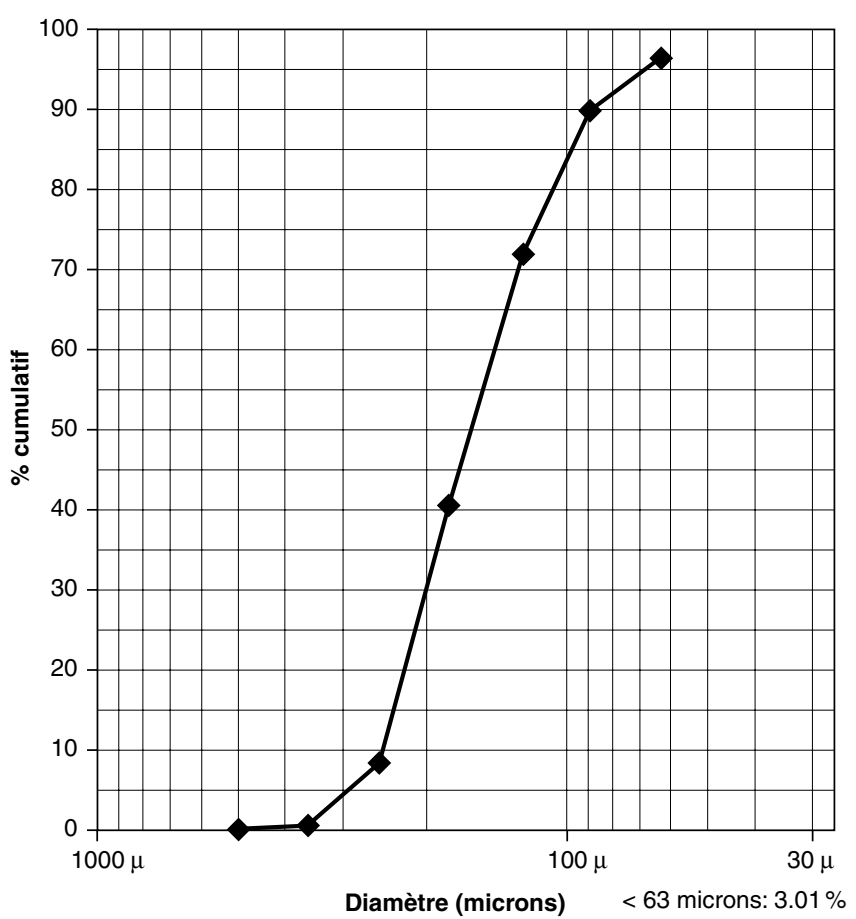

FIGURE 8. Grain size of the sand filling the inner part of horizontal pipes at Saint-Joachim.

Courbe granulométrique du sable composant la partie interne des structures cylindriques horizontales à Saint-Joachim.
TABLE I

Dimensions of pipes (in centimetres)

\begin{tabular}{cccc}
\hline No. & Diameter & $\begin{array}{c}\text { Minimum } \\
\text { length }\end{array}$ & $\begin{array}{c}\text { Distance } \\
\text { between pipes }\end{array}$ \\
\hline 1 & 12 & 40 & \\
2 & 12 & 59 & $1 \& 2: 8$ \\
3 & 13 & 52 & $2 \& 3: 25$ \\
4 & 14.5 & 34 & $3 \& 4: 16$ \\
5 & 6.5 & 41 & $4 \& 5: 3$ \\
6 & 14.5 & 48 & $5 \& 6: 15$ \\
\hline
\end{tabular}

such as those reported by Allen (1961). It is suggested that water under pressure was most likely expelled on the delta front escarpment rather than vertically to the surface which is more common for escape structures and suffosion.

Were the pipes formed contemporaneously with sedimentation or sometime later? Were they formed in a shallow-water environment or a terrestrial environment? Although it is difficult to resolve these questions, we believe that pipes are a postemergence feature. They may date back to the early Holocene. There is no evidence that pipes have a cryogenic origin or are related to a seismic event although Plaziat and Poisson (1992) suggested that occurence of vertical pipes in cluster is considered to be seismogenic. Similarly, a vertical cylindrical structure in upper Miocene sand and gravel in Brittany has been also attributed to paleoseismicity by Van Vliet-Lanoë (2005: Fig. 11.71, p. 304).

\section{CONCLUSION}

Horizontal cylindrical structures (pipes) can form under certain conditions and be preserved in unconsolidated sediments. These structures resulted from groundwater flowing under hydraulic pressure. Oxydation or cementation by a chemical solution (iron or carbonate for example) is required to consolidate the outer ring. In the Saint-Joachim delta, water was expelled out through small cavities running to the front of the escarpment when the deposit emerged from the postglacial Goldthwait Sea. The two non permeable silty clay layers constrained water flow and probably prohibited water from reaching the surface as springs. This is the reason why no vertical pipes are apparently associated with the horizontal structures. The rarity of such structures in unconsolidated sediment and bedrock suggest that particular conditions are necessary for their formation and preservation.

\section{ACKNOWLEDGEMENTS}

The site of horizontal pipes was reported to the senior author by Martin Lebel, while he was an undergraduate student at the Université Laval. Illustrations were prepared for publication by the Service de Cartographie of the Département de Géographie. A preliminary version was reviewed by Dr. Matthew Hatvany. We also acknowledge with thanks remarks and suggestions made by the reviewers, the editor and Dr. Daniel Fortier, who also made grain-size analysis. 


\section{REFERENCES}

Allen, J.R.L., 1961. Sandstone-plugged Pipes in the Lower Old Red Sandstone of Shropshire, England. Journal of Sedimentary Petrology, 31: 325-335.

Allen, J.R.L., 1984. Sedimentary Structures. Their Characteristics and Physical Basis. Elsevier, Amsterdam, 663 p.

Baerman, A., Iwanoff, A., and Wilke, H., 1983. The calcium carbonate content of north German tills, p. 259-262. In J. Elhers, ed., Glacial deposits in Northwest Europe. Balkema, Rotterdam, $470 \mathrm{p}$.

Collinson, J.D. and Thomson, B., 1982. Sedimentary Structures. Unwin Hyman, London, $194 \mathrm{p}$.

Conybeare, C.E.B. and Crook, K.A.W., 1968. Manual of Sedimentary Structures. Bureau of Mineral Resources (Geology and Geophysics), Canberra, 327 p.

Curran, H.A. and Frey, R.W., 1975. Pleistocene Structures, p. 365-376. In R.W. Frey, ed., The study of trace fossil. Springer-Verlag, New York, 562 p.

Dionne, J.C., 1960. Observations sur les colonnes de grès de la région de Kingston, Ontario. Revue canadienne de Géographie, 14: 59-61.

Dionne, J.C., 1973. Structures cylindriques verticales dans du Quaternaire à Arthabasca, Québec. Sedimentary Geology, 9: 53-63.

Dionne, J.C. and Gangloff, P., 1975. Vertical Cylindrical Structures in Quaternary Deposits, Southern Québec. Geological Society of America, Northeast Section Annual Meeting, Abstracts with Programs, 7: 49.

Dionne, J.C. and Laverdière, C., 1972. Structure cylindrique verticale dans un dépôt meuble quaternaire, au Nord de Montréal, Québec. Canadian Journal of Earth Sciences, 9: 528-543.

Dionne, J.C. and Pérez Alberti, A., 2000. Structures cylindriques verticales dans un dépôt quaternaire, en Galice (Espagne). Géographie physique et Quaternaire, 54: 343-349.

Gangloff, P., 1974. Les structures cylindriques et l'évolution géomorphologique d'une plage tardiglaciaire à Saint-Jérôme, Québec. Revue de Géographie de Montréal, 28: 357-373.

Gubler, Y., ed., 1966. Essai de nomenclature et caractérisation des principales structures sédimentaires. Technip, Paris, $291 \mathrm{p}$.
Hawley, J.E. and Hart, R.C., 1934. Cylindrical Structures in Sandstone. Geological Sociey of America Bulletin, 45: 1017-1034.

Jensen, J.P. and Miller, J., 1990. Vertical cyclindrical Structures in Danish Quaternary (Weichselian) glaciofluvial deposits: their description and genesis. Bulletin of Geological Sociey of Denmark, 38: 59-67.

Kavanagh, S.J., 1888-1889. On Modern Concretions from the St. Lawrence; with Remarks (by J.W. Dawson) on Cylinders found in the Postdam Sandstone. Canadian Record of Science, 3: 292-294.

Klein, G. de Vries, 1977. Clastic tidal facies. Continuing Education Publishing Company, Illinois, $149 \mathrm{p}$.

Laliberté, S., 2005. Sédimentologie et stratigraphie d'un delta édifié dans un contexte de régression forcée: exemple du delta de la rivière Sainte-Anne. Unpublished M.Sc. Thesis, Département de géographie, Université Laval, $92 \mathrm{p}$.

LaSalle, P., 1978. Géologie des sédiments de surface de la région de Québec. Ministère des Richesses naturelles, Québec, Rapport DPV-565, 22 p.

Lebel, M., 2001. Paléogéographie de la région de St-Joachim: sédimentologie et stratigraphie. Mémoire de baccalauréat non publié, Département de géographie, Université Laval, $51 \mathrm{p}$.

Pettijohn, F.J. and Potter, P.E., 1964. Atlas and Glossary of Primary Sedimentary Structures. Springer-Verlag, New York, $370 \mathrm{p}$

Picard, M.D. and High, L.R., 1973. Sedimentary Structures of Ephemeral Streams. Elsevier, Amsterdam, $223 \mathrm{p}$.

Plaziat, J.C. and Poisson, A.M., 1992. Mise en évidence de plusieurs séismes majeurs dans le Stampien supérieur continental au sud de Paris: enregistrements sédimentaires de la tectonique oligocène. Bulletin de la Société géologique de France, 163: 541-551.

Ricci Lucchi, F.R., 1995. Sedimentograhica: A Photographic Atlas of Sedimentary Structures. Columbia University Press, New York, 255 p.

Todd., J.E., 1896. Loglike Concretions and Fossil Shores. American Geologist, 17: $247-249$.

Van Vliet-Lanoë, B., 2005. La planète des glaces. Vuibert, Paris, 470 p. 